\title{
Study on Village Cadres' Working Enthusiasm on Voluntary Provision of Village-level Public Goods: Take "One Case, One Meeting" System as an Example
}

\author{
Xiuyi $\mathrm{Li}^{1.2}$,Weiping $\mathrm{Liu}^{1 . *}$ and Xiaoyan Xing ${ }^{3}$ \\ ${ }^{1}$ School of Economics, Fujian Agriculture and Forestry University, Fuzhou, Fujian, China \\ ${ }^{2}$ School of Public Affairs, Fujian Jiangxia University, Fuzhou, Fujian, China \\ ${ }^{3}$ Departments of Management, Fujian Chuanzheng Communications College, Fuzhou, Fujian, China \\ Corresponding author: 1wp789326@126.com
}

\begin{abstract}
Because of the collaborative dilemma in the "One Case, One Meeting" system, the villagers cannot agree on village-level public goods supply. After the financial rewards and subsidy innovation in 2008, many villages were witnessed to break through the collaborative dilemma. Village cadres has played a key role on the provision of village-level public goods in the "One Case, One Meeting" system.which factors transform village cadres' behavior from "idleness" to "entrepreneur"?Based on "One Case, One Meeting” cases in Fujian Province, by means of quantitative analysis, the paper obtained a results that national performance assessment, election and villagers' meeting have significant impact on village cadres' work enthusiasm .
\end{abstract}

\section{Introduction}

\subsection{Background}

China's rural public goods supply mechanism has undergone tremendous changes since 2000: the supply of basic public goods and services in rural areas was up to government finance; whereas the supply of village-public goods such as small village irrigation, village road and bridges, sanitation facilities, public facilities used inclusively by villagers was up to "one case, one meeting" system, which means it is the villagers who discuss, decide, finance the villagelevel public goods, and it is the village cadres who construct the village-level public goods .

\subsection{Issues raised}

Statistics from the Ministry of Finance showed that the number of villages built public projects through the "One Case, One Meeting" mechanism accumulated to 2008 was less than $10 \%$ [1].The government innovated the mechanism by providing financial awards to match investment from villagers, accounting for $50 \%$ of villagers' investment, [2]. Good results were achieved by this innovation: data from the Ministry of Finance showed by 2012, the number increased from $14 \%$ in 2008 to $37.3 \%$ [1].Data from Department of Finance of Fujian province, the number of villages received financial awards was 7443 , accounting for $51.56 \%$ only in the year 2011 .

More and more villages were witnessed to have built public goods after financial rewards and subsidy being provide $\mathrm{d}$ to the construction. The motivation of villagers can be attributed to the financial rewards.: Most scholars attributed the reduction of villagers cooperation cost and improvement of villagers' participatory enthusiasm to the successful implementation of financial awards, neglected or not gave due attention to roles played by village cadres. In fact, village cadres pay a huge effort to integration of the villagers' will, funds collection, project construction and maintenance [3,4]. Some scholars noticed village cadres' key role in the development of "one case, one meeting" project, what factors motivate them to put on efforts to the supply of rural public goods? The existing research gave no further discourse $[5,6]$.This essay will take village construction of public goods in Fujian Province as an example, in order to identify factors contributing to villager cadres' working enthusiasm, and what can do to improve their enthusiasm. 


\section{Text theoretical analysis of influential factors of village cadres' behavior}

Village main cadres (including village chief and village secretary) are elected by villagers, but employed and assessed by town government, so their behavior is also subject to the dual constraints from demands of both villagers and government. Oi Jean and others noted as "dual representative of the interests of the government and villagers," village cadres strike a balance between the will of the government, the requirements of villagers and their interests [7].This paper holds that financial awards encouraged villagers to participate actively in "one case, one meeting" program, also asked the village cadres to actively contribute to public welfare projects, government motivated village cadres by adjusting the village cadres performance evaluation indicators, putting more importance to village public construction. That is to say, the dual pressures from both villagers and government have substantial influence on village cadres' behavior. L. J. Li and others noted that their behavior was impacted by wages and job generation method [8]; L. X. Zhang noted that gender of village cadres, and village scale also affect their behavior [9]. So this paper argues that:Town government influence village cadres' behavior through performance appraisal, villages influence village cadres' behavior through the villagers' democratic.

\section{Variables and the model}

\subsection{Data sources}

From January 2013 to March 2013, the author had conducted a questionnaire survey on village cadres from 203 villages in the prefecture-level city in Fujian. Survey data show that only $9.6 \%$ of the villages had carried out village-level public construction before 2008, and from 2009 to March 2013 we witnessed the ratio was $70.86 \%$, with 256 public projects constructed in total. Village cadres played a key role in the process, with $58.58 \%$ and $89.45 \%$ being initiated and implemented by the village committee respectively.

\subsection{Variables description}

The dependent variable is the estimated ratio of time village cadres' spending on the "one case, one meeting" issues versus total working time. Based on data of the ratio in 2012, the author assumed that:the higher the ratio, the better.

Main independent variables are as follows:

(1)Influences from government. Firstly, the proportion of score allocated to public welfare project in the performance appraisal system.village cadres will invest more time on the village-level public goods when the town government lay more emphasis on this issue We assumed that: more emphasis on construction of village-level public and higher wages prompt village cadres to put more time in public issues.

(2)Influences from villagers. Firstly, because of village cadres' being elected by villagers, they respond positively to villagers' requirements.Secondly, the villagers meeting times. We assumed that: more meeting times prompt village cadres to put more time in public issues.

Control variables are as follows:

(1)The village characteristic variables.the village numbers, distance from village to town.

(2) The village cadre's personal characteristics. Village cadres age, education level, gender will also affect the ratio. We assign "1" for male, "0" for female. Female cadres may want to spend more time on family compared to male, so gender may have influence on time spent on public issues.

(3) How much village migrant workers are paid also has impact on the ratio. Being village cadres means giving up the wage obtained as migrant workers. So we assumed that: the more village migrant workers earn, the less the ratio.

\subsection{The model}

The model is to test the compound impact of government and villagers on the dependent variable:

$$
\begin{aligned}
& \text { Tratio }=c_{0}+\beta_{1} \text { score }+\beta_{2} \text { wage }+\beta_{3} \text { meeting }+\beta_{4} \text { title } \\
& +\beta_{5} \text { controls }+\mu
\end{aligned}
$$

Variable Tratio refers to time percentage of village cadres' spending on rural public goods, which is a continuous variable.Variable score refers to the proportion of score allocated to public goods project in the performance appraisal system, a continuous variable too. The aforementioned two variables are measured by percentage.Variable wage denotes village cadres' position wage.Variable meeting refers to meeting times of villager representative in a year, title is a zero, one binary variable,with 0 coded for village secretary, 1 coded for village director.The controls denotes control variables as follows: villagers group ,village cadres' age(measured by year),village cadres' education (measured by year), gender(coded as a zero, one binary variable, with 1 coded for males), and migrant wage (village migrant annual income measured by ten thousand yuan), distance (distance from village to town) 


\section{Empirical results and analysis}

Based on main variables' statistical features, using STAT12 statistical software to process data, taking OLS estimation method, a one-time regression. the regression results in Table 1 show that the model simulation is better, goodness of fit is 0.3272 ; and at $1 \%$ significance level. Specific analysis of the results is as follows:

Table 1. Regression results.

\begin{tabular}{|c|c|c|c|c|}
\hline Variable & $\begin{array}{c}\text { coeffici } \\
\text { ent }\end{array}$ & $\begin{array}{l}\text { standard } \\
\text { deviation }\end{array}$ & $\mathrm{t}$ & $\mathrm{p}$ \\
\hline Score & 2.676 & 0.175 & 14.54 & $0.000 * * *$ \\
\hline Wage & 0.133 & 1.172 & 0.11 & 0.909 \\
\hline Meeting & 2.168 & 0.386 & 5.63 & $0.000 * * *$ \\
\hline Title & 3.191 & 1.021 & 3.13 & $0.018 * *$ \\
\hline $\begin{array}{l}\text { Villages } \\
\text { group }\end{array}$ & 0.078 & 0.039 & 1.98 & $0.058^{*}$ \\
\hline $\begin{array}{c}\text { Migrant } \\
\text { wage }\end{array}$ & -0.002 & 0.001 & -2.59 & $0.051^{*}$ \\
\hline Distance & 0.055 & 0.132 & 0.42 & 0.675 \\
\hline $\begin{array}{c}\text { Educatio } \\
\mathrm{n}\end{array}$ & -0.058 & 0.236 & -0.26 & 0.794 \\
\hline Age & -0.062 & 0.118 & 0.52 & 0.602 \\
\hline Gender & 0.141 & 2.018 & 0.007 & 0.944 \\
\hline $\mathrm{C}$ & 0.431 & 5.843 & 0.01 & 0.995 \\
\hline $\begin{array}{c}\text { F( 11, } \\
\text { R-square }\end{array}$ & \multicolumn{3}{|c|}{$287)=13.27$} & $\begin{array}{c}0.0000 \\
=0.3118\end{array}$ \\
\hline
\end{tabular}

From results listed in Table 1, we can conclude that:

(1) Influence from government .Firstly, the regression shows the influence of performance appraisal on village cadres' working time spent on public welfare, if government putting more importance to village-level public goods in the performance appraisal system, can significantly affect village cadres' working time ratio in the "One Case,One Meeting",significant at the 1\% statistical level; secondly, influence of salary on village cadres' working time ratio is positive, but not significant, which means the role of salary in motivating village cadres is not as important as imagined. Many village cadres surveyed claimed that they pay more attention to the right to collective resource allocation, contact brought to their business, and the corresponding fame status, social security.

(2) Influence from villagers. Firstly, the meeting number of villagers has a positive impact on time spent on "one case, one meeting" by village cadres and significant at the $1 \%$ statistical level.As a formal way to express the will of the villagers,meeting plays an important role in coordinating the interests of different villagers and strengthening the villagers' cooperation, furthermore exerting pressure on the village cadres to work enthusiastically.Secondly, the election procedure contributes to enthusiasm for work, and positively affects the village director' enthusiasm more than the village secretary', significant at the $5 \%$ statistical level.

(3) Influence from control factors. Firstly, the village migrant workers' wages have a negative influence on village cadres' working time, but significant only at the $10 \%$ statistical level. Maybe village cadres are deprived of other working opportunities, the more village migrant workers' wages earn, the more opportunity cost to village cadres, the less time they put in "one case, one meeting". Secondly, the number of group has positive effect on village cadres' working time, and significant at the $10 \%$ statistical level.

\section{Conclusions and policy recommendations}

Empirical results show village cadres, are "double agent of government and villagers ",whose time spent on "one case, one meeting" issues is significantly affected by requirement of government and villagers. The impact of wages is not significant, perhaps non-wage returns brought by the position is more valued than a specific salary.

Based on these conclusions, in order to motivate village cadres spent more time on "one case, one meeting" system, several recommendations are raised to further motivate village cadres.

Firstly, More importance should be laid on the rural public goods supply in village cadres' performance appraisal system.improve village cadres' performance evaluation mechanism to make "village public welfare projects" account for prominent share; determine village cadres in reference to migrant workers' wages, make sure it is equal to or 
moderately above migrant workers' wages, basic wage should be correlated to village scale; while combine wage and non-wage motivations, we should notice that hidden motivation, intrinsic motivation, and prestige incentives also play due role in motivating village cadres.

Secondly, fully employ role of villagers' meeting, make sure meeting be held regularly, to supervise village cadres' behavior; plus, perfect the direct election mechanism, make the election of village cadres reflects villagers' demands.

Last, strengthen cooperation between government and villagers, common requirements of the two party can promote the "double agent" to devote more energy to "one case, one meeting" issues.

\section{Acknowledgements}

This paper is one of the periodic accomplishments of the National Social Science Fund Project, namely, "government - Village relations and crack of dilemma of collective action in the supply of village -level public goods (15BGL178).

\section{References}

1. Liu, H. and Yan, H. (2008), "The problems and solutions of 'One Case One Meeting' system aboutthe village-level public goods", Truth Seeking, Vol. 8, pp. 89-92.

2. Li Xiuyi, Liu Weiping;The Solution to the Cooperation Dilemma in rural after the Complementation of Financial Reward - - a Case Study about 39 Villages in Fujian,Journal of Agro-Forestry Economics and Management,vol. 14 (2015), p.91-100.(In Chinese).

3. Zhou Mi, Zhang Guangsheng: The Operation Mechanism of "One Case, One Meeting" System and its Applicability, Issues in Agricultural Economy, 2010 ,No.2, p.38-43.(In Chinese).

4. Tu Shengwei: Community,Enterprise,Cooperative Organization and Rural Public Goods Supply,Economic Science Press,China,2011:22-24.(In Chinese).

5. Liu, H. and Yan, H. (2008), "The problems and solutions of 'One Case One Meeting' system about the village-level public goods” , Truth Seeking, Vol. 8, pp. 89-92.

6. Chenjie,Liu Weiping,Yu Liyan: Study on Performance and evaluation of "One Case, One Meeting”financial subsidy system - - take Fujian Province as an example,Fujian Tribune (The Humanities \& Social Sciences Bimonthly), 2013,No.9, p.135-138.(In Chinese).

7. JC. Oi , S. Rozelle:Elections and Power: The Locus of Decision-making in Chinese Villages, The China Quarterly, 2000,No. 162, p.513-523.

8. L.J. Li:Elections and Popular Resistance in Rural China, China Information, vol. 15 (2001) No.2, p.2-15.

9. Zhang Linxiu,Luo Renfu,Liu Chengfang,Scott Rozelle.An Analysis on the Determinants of Public Good Investment in China's Rural Communities, Economic Research Journal, 2005,No.11, p.76-83. (In Chinese). 